\title{
STUDENTS' OPINIONS REGARDING SELF-EMPLOYMENT OPPORTUNITIES IN AGRICULTURE, AT THE NATIONAL UNIVERSITY OF LESOTHO.
}

\author{
Lesaane T. C ${ }^{1}$ and Akintunde M. A. $\mathrm{O}^{2}$. \\ Correspondence author: M. A. O. Akintunde. Email: AkintundeMAO@ufs.ac.za
}

\begin{abstract}
Most developing countries including Lesotho, faces a major challenge of creating jobs for their high education graduates. This matter hard presses policy makers to advocate for training which equips graduates to venture into self-employment for job creation. This study therefore intended to establish students' opinions regarding self-employment opportunities in agriculture. The key objectives were: to describe students' knowledge of potential selfemployment opportunities in agriculture; to assess students' willingness to engage in selfemployment in agriculture; to identify factors constraining graduates from venturing into selfemployment in agriculture. Sixty-six final year students in the faculty of agriculture were purposefully selected for the study. A structured questionnaire was used as a data collection instrument for this study and data were analysed descriptively using statistical indicators including percentages, mean and standard deviation. Findings revealed that Students perceived that agriculture has a potential of creating employment for huge number of people and they are willing to undergo agri-business after completion of their studies. It is therefore recommended that practical agribusiness training be included in undergraduate agriculture curriculum to entrench this skill. The government should support agricultural graduates by addressing all the identified constraints such as marketing, input supply, credit, training, extension services and poor storage facilities.
\end{abstract}

Keywords: Students’ opinions, Self-employment, Agriculture, Agri-business.

\section{INTRODUCTION}

According to World Bank (2008), about 65\% of the total labour force in Africa are employed in agricultural-related jobs, and this accounts for about one-third of the gross domestic product. However, this substantial contribution of agriculture to the economy still remain low in subSaharan Africa. One of the reasons for the decline has been attributed to reduction in labour and skills due to shortage of youth participation in agriculture (Ibitoye, 2011).

Self-employment in agriculture means people working on their own farms or doing any other income-generating activities such as buying and selling of agricultural products or inputs. (Lemma, 2014). Self-employment contributes to the creation of national wealth and job opportunities and stimulating agricultural output growth, and is also expected to have an associated increase in non-farm employment through input linkage (AGCAS, 2016).

\footnotetext{
${ }^{1}$ MSc student at the National University of Lesotho (NUL). Dept of Agricultural economics and extension, Faculty of Agriculture, P. O. Box 180 Roma, Lesotho. Email: takatsolesaane@gmail.com

${ }^{2}$ Postdoctoral Research Fellow: SANRAL Research Chair, Faculty of Education, Dept of Mathematics, Natural Science and Education Technology, University of the Free State, P. O. Box 339, Bloemfontein 9300, South Africa, Tel. 0514012238. Email: AkintundeMAO@ufs.ac.za, ORCID: 0000-0001-7424-2406
} 
Commercial intensive farming mostly involves a large field and or number of animals and large resource inputs such as pesticides, fertilizers and a high level of mechanization. These agricultural operations, from both subsistence and commercial farming, generally attempt to maximize financial income from the products (Bareja, 2014). Youths perceive farming as being for school drop-outs and illiterates; probably because they do not get enough encouragement from their agricultural professional parents (Olorunfemi, Oladipo, Oladele \& Oladele, 2016). This has therefore led to a strong apathy by the youth towards agriculture as an occupation for the less privileged and the aged in the society (Adekunle, Olorunfemi, Adesiji, Oladipo, Matanmi, \& Malomo, 2015).

Agriculture offers a lot of attractive activities and business, therefore, the transformation of the agriculture sector towards money-making endeavours will contribute towards change in perceptions of society and the public towards entrepreneurship (Mibey, 2015). Mechanisms must be put in place to help youth engage in sustainable agriculture, and should include promotion of land reforms and creation of laws that ensure young people's access to production resources that ensure equal opportunities for young men and women (Ahaibwe, Mbowa \& Lwanga (2013).

Land is one of the major factors of production but it is difficult for young farmers to have access to land because parents hold ownership of land, leaving young farmers with small or no piece of land, and yet, for agriculture to be profitable, the need for land cannot be overemphasized (Mibey, 2015). According to Nwaogwugwu \& Obele (2017) land is also an important factor limiting youth participation in agriculture-based professions, others are poor social values, poor agricultural support services, environment related land degradation factors, poor agricultural policies, industrialization and poor health conditions. Youth often have to wait many years before inheriting their share of the family land and those with many siblings end up inheriting just a very small piece. Goemans and Giudiani (2014) cited two examples of how land would be available to young farmers. In one example, the Taiwan Council of Agriculture encourages elderly farmers to lease their land on a long-term basis to young farmers and to farmers' organizations. In another example is the case of Rivall Uganda Limited (RUL), a trading firm dealing with an extensive range of food grains, vegetable oil and honey, entering into short-term lease agreement with landowners that did not wish or did not have the capacity to utilize land in the foreseeable 12 months. The RUL worked closely with local authorities to sensitize landowners with regard to youth and their need for access to land and also encouraged landowners to lease their land to the youth. These examples demonstrate different ways that youths can be motivated to engage in agriculture.

Agriculture, like any other entrepreneurial entity, requires start-up capital which is a very crucial element without which the business cannot commence. However, most young people do not have access to funding for agricultural purposes (Mibey, 2015). Most graduates are from poor families and in the eyes of banks; these types of consumers lack both the experience and security in terms of assets and guarantors (Dahles \& Wakkess, 2012).

In many developing countries, smallholders have difficulty in buying good quality affordable inputs and selling their products in steady quantities at a fair price, while middlemen have access to market information and are in a position to determine the price to offer for produce (Goemans and Giudiani, 2014). Furthermore, free trade has resulted in an increase of imports 
into developing countries, leading to an influx of cheap products from countries like China and India, which have tended to cripple local production (Dahles \& Wakkess, 2012).

Agriculture is a powerful sector to create jobs for at least half of both educated and uneducated people and plays a role in the development of African's economy (Fields, Margolis, \& Gindling 2014). This is in line with observation by Liu (2014) that agriculture is up to four times more effective than other sectors in reducing poverty.

A huge number of educated African youths enter the labour market every year, but the market capacity is no longer enough to hold the number (Fox, Senbet, \& Simbanegavi, 2016). Agriculture graduates are not an exception to this situation and given the critical knowledge and skills in their possession, they believed that they have potential to start agricultural enterprises and generate employment and income through commercialized agriculture (Zakaria, Adam \& Abujaja, 2013). However, this is currently not the case and agriculture graduates form part of the unemployed population while agricultural land remains underutilized. There is, therefore, need to ascertain the opinions of university students regarding selfemployment opportunities in agriculture as a basis for exploring ways of opening up new awareness for their self-employment. The main objective of this study is to establish students' opinions regarding self-employment opportunities in agriculture in order to assess their willingness to engage in self-employment in agriculture.

\section{METHODOLOGY}

The study was carried out at the National University of Lesotho, the only public university in the country. This university is located in Roma, about 29 kilometres from the capital, Maseru. The focus was on 66 final year students of 2017/2018 academic year in the selected programs: Bachelor of Science degree in Agricultural Economics, Agricultural Extension, Animal Science, Crop Science and Consumer Sciences. This group of students were selected because they will soon go into labour market. Data were collected between January and April, using questionnaire that contained close-ended questions and items. The instrument was developed with the aid of literature and consultation with experts. The instrument covered key aspects like demographic characteristic of respondents, students' willingness to engage in selfemployment in agriculture and factors constraining graduates from venturing into selfemployment in agriculture.

Data were analysed using descriptive statistics of the Statistical Package for Social Science (SPSS) computer programme version 16.0. The statistical indicators used included frequencies, percentages, means and standard deviations and the findings were presented in tabular form.

\section{RESULTS AND DISCUSSION}

\subsection{Demographic characteristics of respondents}

Table 1 presents the demographic characteristics of respondents. The findings on the distribution of respondents by sex reveal that $51.5 \%$ of respondents were males and $48.5 \%$ were females. Slight increase in the number of males could be attributed to the fact that agricultural activities are usually under the control of men in Lesotho. Furthermore, relatively large percentage of respondents were aged 21-25 years (47\%), 26-30 years (36.4\%), 31-35 
years $(7.6 \%), 35$ years and above $(6.1 \%), 15-20$ years $(1.5 \%)$ and $1.5 \%$ did not want to disclose their age.

Table 1 Demographic characteristics of respondents $(n=66)$

\begin{tabular}{|l|c|c|}
\hline Variables & Frequency & Percentage \\
\hline Gender & 34 & $51.5 \%$ \\
\hline Male & 32 & $48.5 \%$ \\
\hline Female & 1 & $1.5 \%$ \\
\hline Age & 31 & $47.0 \%$ \\
\hline $15-20$ & 24 & $36.4 \%$ \\
\hline $21-25$ & 5 & $7.6 \%$ \\
\hline $26-30$ & 4 & $6.1 \%$ \\
\hline $31-35$ & 1 & $1.5 \%$ \\
\hline 35 and above & & $31.8 \%$ \\
\hline Missing & 21 & $68.2 \%$ \\
\hline Marital Status & 45 & \\
\hline Married & & $71.2 \%$ \\
\hline Single & 47 & $19.7 \%$ \\
\hline Family Size & 13 & $6.1 \%$ \\
\hline $1-5$ & 4 & $3.0 \%$ \\
\hline $5-10$ & 2 & $34.8 \%$ \\
\hline 10 and above & & $65.2 \%$ \\
\hline Missing & 23 & \\
\hline Educational Level & 43 & \\
\hline Diploma & & \\
\hline High school education & & \\
\hline Source: Fis Survey 2018 & & \\
\hline
\end{tabular}

Source: Field Survey, 2018

Regarding marital status, majority $(68.2 \%)$ of respondents was single and $31.8 \%$ were married. This finding is similar to Zakaria et al. (2013), from the University for Development Studies, Ghana. The findings also reveal that majority (71.2\%) has a family size of $1-5,19.7 \%$ has 5 10 people, $6.1 \%$ has 10 people and above and $3 \%$ did not indicate their family size. Regarding educational level, majority of the respondents (65.2\%) acquired high school education and $34.8 \%$ had diploma. This indicates that most of the respondents came to the University straight from high school. In a similar study in Ghana, Zakaria et al. (2014) reported that age, marital status, place of domicile, parental educational background of students, practical agricultural experience and risks tolerance were found to have significant influence on students' intention to take up agribusiness as a source of future self-employment avenue or not. This further emphasized the role of demographic characteristics of students in deciding future employment. 


\subsection{Students' willingness to engage in self-employment in agriculture}

Table 2 presents the results of assessing students' willingness to be engaged in selfemployment in agriculture. The findings indicated that $22.7 \%$ of the respondents are currently self-employed, $75.8 \%$ are not self-employed and $1.5 \%$ did not respond to this part. Majority $(68.1 \%)$ of the respondents prefer to be self-employed after graduation, $16.7 \%$ prefer to work in government or private sectors, $3 \%$ prefer to continue with family business and $12.1 \%$ have no idea of what to do after graduation. This implies that graduates are willing to go into selfemployment in agriculture if environments are conducive enough. This trend confirms that more people are willing to set up their own business outfit rather than working for someone else.

Table 2 Assessment of students' willingness to be engaged in self-employment in agriculture $(n=66)$

\begin{tabular}{|l|c|c|}
\hline Students' willingness & Frequency & Percentage \\
\hline Are you currently self-employed? & & \\
\hline Yes & 15 & $22.7 \%$ \\
\hline No & 50 & $75.8 \%$ \\
\hline Missing & 1 & $1.5 \%$ \\
\hline Job preference after graduation & 45 & \\
\hline Self-employed & 11 & $68.1 \%$ \\
\hline Government/private employment & 2 & $16.7 \%$ \\
\hline Continue with family business & 8 & $3.0 \%$ \\
\hline Not sure & & $12.1 \%$ \\
\hline Engaged in agriculture activities apart from school & 47 & \\
\hline Yes & 19 & $71.2 \%$ \\
\hline No & & $28.8 \%$ \\
\hline Willing to be in agri-business after graduation & 59 & \\
\hline Yes & 7 & $89.4 \%$ \\
\hline No & & $10.6 \%$ \\
\hline Preferred agri-business section & 31 & \\
\hline Livestock & 15 & $47.0 \%$ \\
\hline Crops & 12 & $22.7 \%$ \\
\hline Consultancy & 3 & $18.2 \%$ \\
\hline Laboratory & 5 & $4.5 \%$ \\
\hline Missing & & $7.6 \%$ \\
\hline Sour: & & \\
\hline
\end{tabular}

Source: Field Survey, 2018

Majority of respondents (71.2\%) were engaged in agricultural activities apart from school practical, and these students perceived practical training as contributing not only to their academic performance but also to their competency level in agriculture which is very important in agribusiness enterprise creation. About twenty-nine percent (28.8\%) take part in agricultural activities at school while majority $(89.4 \%)$ of the respondents are willing to be engaged in agribusiness after completion of study; only $10.6 \%$ of respondents were not interested in agribusiness. Interest in agribusiness may be due to preference of respondents to be selfemployed after their study. These findings were contrary to that of Zakaria et al. (2013) which revealed that majority of his respondents showed no interest of being engaged in agribusiness 
after graduation. Those interested in being engaged in agri-business are willing to take part in different sections including Livestock (47\%), Crops (22.7\%), Consultancy (18.2\%), and Laboratory $(4.5 \%)$ as their most preferred agribusiness enterprises and $7.6 \%$ did not respond to this part of the question. These findings did not show any correlation between respondents' field of study and area of agribusiness they are interested in.

\subsection{Factors constraining graduates from venturing into self-employment in agriculture}

The study sought to determine Respondents' perception of factors constraining them from venturing into self-employment in agriculture. This was done by seeking their level of agreement with selected opinions using a 5-point Likert scale anchored as follows: Strongly disagree $=1$, Disagree $=2$, Undecided $=3$, Agree $=4$ and Strongly agree $=5$. For purposes of interpretation of findings, mean ranging from 3.0 and above were taken to imply agreement with the statement and are taking as not been constraints. Mean below 3.0 imply disagreement with the statement are considered to be constraints to graduate from venturing into agribusiness. In addition, standard deviation of 1.00 or below was interpreted to imply close similarity in opinions among respondents, and those above 1 to imply variation in their opinions.

Table 3 Perceived constraints to self-employment in agriculture (n=66)

\begin{tabular}{|l|c|c|}
\hline Statement about constraints & Mean & SD \\
\hline Access to production land for agri-business projects. & 2.64 & 1.17 \\
\hline Bank loans are available for youth. & 2.17 & 1.17 \\
\hline Agriculture is a profitable business. & 2.59 & 1.28 \\
\hline Attendance of agricultural training workshops. & 1.88 & 0.83 \\
\hline Adequate extension services & 2.02 & 1.04 \\
\hline Availability of agricultural supplies and inputs. & 2.52 & 1.19 \\
\hline Good agricultural storage and marketing facilities. & 1.94 & 1.05 \\
\hline $\begin{array}{l}\text { Good and passable road networks to transport products and } \\
\text { inputs. }\end{array}$ & 2.00 & 1.10 \\
\hline Overall & 2.57 & 1.16 \\
\hline
\end{tabular}

Source: Field Survey, 2018

The findings, as summarized in Table 3 indicated that majority of respondents disagreed with the statements; this means that these factors were constraints to graduates from venturing into self-employment in agriculture. The mean ranges from 1.88 to 3.95 with the overall mean being 2.57. The standard deviation ranged from 0.83 to 1.46 with the overall of 1.16 which shows that there was variation in the opinions of the respondents.

Specifically, respondents disagreed with the following opinions regarding factors constraining graduates from venturing into self-employment in agriculture. Therefore, these are identified constraints preventing respondents venturing into self-employment in agriculture: Access to production land for agri-business projects (Mean $=2.64$ ); Agriculture is a profitable business (Mean = 2.59); Availability of agricultural supplies and inputs (Mean = 2.52); Bank loans are available for youth (Mean = 2.17); Adequate extension services (Mean =2.02); Good and 
passable road networks to transport products and inputs (Mean $=2.00$ ); Good agricultural storage and marketing facilities (Mean $=1.94$ ) and Attendance of agricultural training workshops $($ Mean $=1.88)$.

These findings reveal that respondents perceived non-availability of land, less profit, lack of inputs and credit, inadequate extension, poor road network, inadequate marketing and in adequate training attendance are serious constraints. This is in line with findings of Ahaibwe et al. (2013) that very few youthful farmers use improved inputs (such as improved seeds, fertilizers, agricultural chemicals and veterinary drugs). They further argued that this will lead to poor rate of adoption of appropriate inputs and agricultural production is likely to remain low and constrain the youth to subsistence farming. Furthermore, the youth are excluded in the ownership and management of critical assets in agricultural production, especially land.

\section{CONCLUSIONS AND RECOMMENDATIONS}

This study has revealed that students are willing to be self-employed through agri-business after completion of their study. This will ensure that they will be employed after their study. It is recommended that practical agribusiness training be included in undergraduate agriculture curriculum to entrench this skill. It is also recommended that the government should support agricultural graduates by addressing all the identified constraints such as marketing, input supply, credit, training, extension services and poor storage facilities.

\section{REFERENCES}

ADEKUNLE, O. A., OlORUNFEMI, O. D., ADESIJI, G. B., OLADIPO, F. O., MATANMI, B. M. \& MALOMO, J. O. 2015. Perception of Secondary School Youths towards Taking Agriculture as a Career in Egbeda Local Government Area, Oyo State, Nigeria. Nassarawa State University Keffi Journal of Science and Technology, 5(2) 130134.

AGCAS. 2016. Agricultural Consultant. Available from https://www.prospects.ac.uk/jobprofiles/agriculture Accessed 10/12/2017.

AHAIBWE, G., MBOWA, S., \& LWANGA, M. M. (2013). Youth Engagement in Agriculture in Uganda: Challenges and Prospects. Economic Policy Research Centre.

BAREJA, B. G. (2014). Available from www.cropsreview.com/what-is-agriculture.html Accessed 09/03/2017.

DAHLES, H. AND WAKKESS, I.A. 2012. Graduates Entrepreneurship in Tanzania: Enables and Hindrances: European Journal of Scientific Research. 76 (3):386-402.

FIELDS, G., MARGOLIS, D., \& GINDLING, T. 2014. Self-Employment and Subsistence Entrepreneurs? The World Bank. http://blogs.worldbank.org/jobs/self-employment-andsubsistence-entrepreneurs.

FOX, L., SENBET, L. W., \& SIMBANEGAVI, W. 2016. Youth employment in Sub-Saharan Africa: Challenges, constraints and opportunities. Journal of African Economies, 25, i3i15. https://doi.org/10.1093/jae/ejv027.

GOEMANS, C. AND GIULIANI, A. 2014. Key challenges and concrete solutions. Youth and Agriculture.

IBITOYE, J. S. 2011. Attitude of Youths towards Career in Agriculture in Kogi State, Nigeria. International Journal of Applied Engineering Research, 6(14), 1683-1693. 
LEMMA, H. 2014. Livestock entrepreneurship as an emerging self-employment option for University graduates in Ethiopia. Ethiopian Journal of Business and Management 6 (4): 2222-2839.

LIU, A. S. 2014. Five reasons why youth should choose agriculture. blogs.worldbank.org/younthink/five-reasons-why-youth-should-choose-agriculture.

MIBEY, M. C. 2015. Factors influencing youth involvement in agribusiness project in Bomet Central sub-country, Kenya. Published M.Sc. Thesis, University of Nairobi.

NWAOGWUGWU, O. \& OBELE, K. 2017. Factors Limiting Youth Participation in Agricultural - Based Livelihoods in Eleme Local Government Area of Niger Delta. Scientia Agriculturea, 3(17), 105-111. http://doi.org/10.15192/PSCP.SA.2017.

OLORUNFEMI, O. D., OLADIPO, F. O., OLADELE, T. O. \& OLADELE, O. I. 2016. Attitudes of agricultural professionals towards their wards taking agriculture as a career in Kwara State, North Central Nigeria, S. Afr. J. Agric. Ext., 44(2)186-194.

WORLD BANK. 2008. The Growth Report: Strategies for Sustained Growth and Inclusive Development. Commission on Growth and Development, World Bank, Washington D.C. DOI: http://dx.doi.org/10.17159/2413-3221/2016/v44n2a425.

ZAKARIA, H., ADAM, H., \& ABUJAJA, A. M. 2013. The Perception of Agricultural Students and Self-Employment in Agribusiness: A Case Study of Students of University for Development Studies, Ghana. International Journal of Research in Commerce and Management, 4(1041), 104-108. Available from https://doi.org/http://ijrcm.org.in/commerce/index.php Accessed 31/08/2018.

ZAKARIA, H., ADAM, H., \& ABUJAJA, A. M. 2014. Assessment of Agricultural Students of University for Development Studies Intention to take up Self- Employment in Agribusiness. International Journal of Information Technology and Business Management, 21(1), 53-67 